\title{
The influence of heel height related on quality of life on the foot in a sample of women
}

\author{
Daniel López-López' \\ Javier Marañon-Medina ${ }^{1}$ \\ Marta Elena Losa-Iglesias ${ }^{2}$ \\ César Calvo-Lobo 3 \\ David Rodríguez-Sanz ${ }^{4}$ \\ Patricia Palomo-López ${ }^{5}$ \\ Ricardo Becerro de Bengoa Vallejo ${ }^{6}$
}

\begin{abstract}
1. Research, Health and Podiatry Unit. Department of Health Sciences. Faculty of Nursing and Podiatry. Universidade da Coruña, Spain. 2. Faculty of Health Sciences. Universidad Rey Juan Carlos, Spain. 3. Nursing and Physical Therapy Department, Institute of Biomedicine (IBIOMED), Faculty of Health Sciences, University of León, Ponferrada, León, Spain 4. Physical Therapy \& Health Sciences Research Group. European University of Madrid, Villaviciosa de Odón, Madrid, Spain. 5. University Center of Plasencia. Universidad de Extremadura, Spain. 6. School of Nursing, Physiotherapy and Podiatry. Universidad Complutense de Madrid, Spain.
\end{abstract}

\section{SUMMARY}

Many women have worn high-heel shoes (HHS) at some point in their lives and many wear them on a daily basis, with higher prevalence between 39\% and 78\% observed in institutional and clinical settings. The purpose of this study was to describe and compare the scores obtained with regard to foot health and health in general in a sample of women that use HHS as opposed to a sample of women without HHS with normalized reference values. A sample of 120 participants with a mean age of $41.94 \pm 13.912$ came to a health center where self-reported data were registered. The subjects with and without HHS were determined and the scores obtained were compared in the Foot Health Status Questionnaire (FHSQ). This questionnaire is made of 13 questions that assess 4 health domains of the feet, namely pain, function, general health and footwear. The women in the HHS group showed a worse quality of life related to health in general and to foot health specifically. Differences between the two groups were evaluated by means of a t-test for independent samples, showing statistical significance $(P<0.01)$. Women with HHS present a negative impact on the quality of life related to foot health.

KEYWORDS: Foot deformities. Foot diseases. Quality of life. Shoes.

\section{INTRODUCTION}

Many women have worn high-heel shoes (HHS) at some point in their lives and many wear them daily basis, ${ }^{1,2}$ with higher prevalence between $39 \%$ and $78 \%$ observed in institutional and clinical settings ${ }^{3,4}$ and representing a huge proportion of the female population.

The increasing popularity of HHS include present day fashion, ${ }^{5}$ part of the professional attire, ${ }^{6}$ social events, ${ }^{3}$ personal expression, ${ }^{7}$ source of authority, ${ }^{8}$ sexual independence, ${ }^{9}$ mark of flaunted femininity, ${ }^{10}$ psychological empowerment and joy. ${ }^{11}$

However, there are consequent negative side ef- fects, such as foot problems, ${ }^{12}$ sprained ankles, ${ }^{13}$ lower back pain, ${ }^{14}$ leg disorders, ${ }^{15}$ hip pain,${ }^{16}$ knee pain, ${ }^{17}$ walking instability, ${ }^{18}$ a high risk of falls ${ }^{19}$ and venous disease symptoms. ${ }^{20}$

Also, walking in HHS causes many orthopedic conditions (e.g., blisters, bunions, hallux valgus, hyperkeratotic lesions, lesser toe deformities). ${ }^{21,22}$

This kind of disorders represent an important public health issue $e^{22}$ and have an important economic impact ${ }^{23}$ to the affected work and personal activity as it happens to women, ${ }^{23}$ all of which can severely impact autonomy, welfare and loss of quality of life. ${ }^{24}$

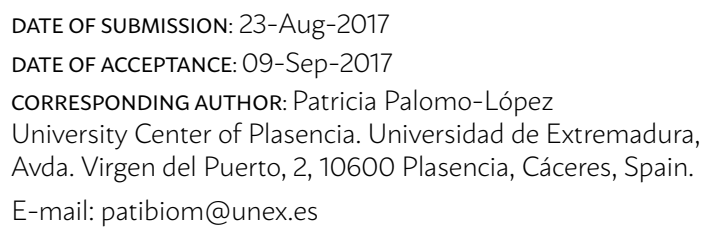

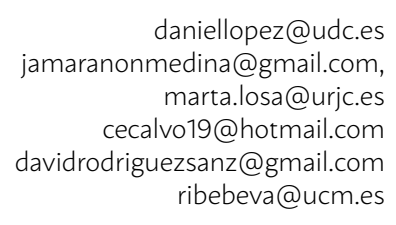

daniellopez@udc.es jamaranonmedina@gmail.com, marta.losa@urjc.es cecalvo19@hotmail.com davidrodriguezsanz@gmail.com ribebeva@ucm.es 
Despite this, up until now, there are no studies that have been able to analyze the quality of life related to foot health in women that wear HHS.

Based on this background and taking into account the existence of unmet care and follow-up care of feet, the purpose of this study was to describe and compare the scores obtained with regard to foot health and health in general in a sample of women that wear HHS as opposed to a sample of women without HHS with normalized reference values.

\section{METHODS}

\section{Design and Sample}

The overall study was completed in 18 months, from January 2014 to June 2015. The study was carried out among women who have been seen at the Clinic of Podiatric Medicine and Surgery, a facility that provides treatment of diseases and disorders of the foot at the University of A Coruña in the city of Ferrol (Spain).

It was a cross sectional study. Data was collected through a randomized sampling method, the criterion for inclusion being between 18 and 65 years old. All of the participants spent the same amount of time walking at the day, including after-work and weekend. The exclusion criterion was a recent history of ankle injury, including sprain, tendinitis, or any muscular pathology in the lower extremity, as well as those who refused to sign the consent form or were incapable of understanding the instructions necessary to carry out the present study. None of the participants had a neurologic condition affecting the lower limbs. ${ }^{25-27}$

\section{Sample size}

Having established a minimal difference score of at least 21 (as clinically relevant) among the groups under study in the FHSQ, and considering that the standard deviation on that scale for the people is around $29^{28,29}$ for a bilateral hypothesis, an alpha risk of $5 \%$ and a statistical power of $80 \%$, and a beta error of $20 \%$, at least 47 cases must be studied in each group $(\mathrm{n}=94)$.

\section{Procedure}

At enrolment, patients were interviewed about general health, demographic characteristics (age and gender) and frequency with which they wore HHS. A single trained examiner performed a standardized clinical exam on all participants measuring height and weight with the subjects barefoot and wearing light clothing. The body mass index (BMI) was calculated from the height $(\mathrm{m})$ and weight $\left(\mathrm{kg}^{2}\right)$, applying the Quetelet's equation BMI=weight / height ${ }^{2} .{ }^{30}$

Then, a measuring tape was used to determine the height of the heel. It was measured vertically from the floor to the top of the heel at the back, including the top piece. The instrument classified the shoes in two groups: with HHS $(>3 \mathrm{~cm})$ and without HHS $(<3 \mathrm{~cm})$. Studies have shown that the discomfort increases with the heel height and that a heel height $>3$ might have adverse effects on the body. ${ }^{31,32}$

Lastly, participants' informants filled out the Foot Health Status Questionnaire (FHSQ). This self-administered questionnaire on health-related quality of life is intended specifically for the foot which is recognized as a valid test. ${ }^{33,34}$ Foot-specific and general health-related quality of life was assessed by using the Foot Health Status Questionnaire (version 1.03) ${ }^{35}$ which comprises three main sections. Section 1 consists of 13 questions reflecting four foot health-related domains (Table 1): foot pain, foot function, footwear, and general foot health. This section has demonstrated a high degree of content, criterion, and construct validity (Cronbach $\alpha=0.89-0.95$ ) and high retest reliability (intraclass correlation coefficient $=0.74-0.92),{ }^{36}$ and it has been shown to be the most appropriate measure of health-related quality of life for women that use high heeled shoes population. ${ }^{37}$

Each domain has a specific number of questions. Four regarding pain, 4 on function, 3 on footwear and 2 on general foot health. The assessment of pain and function is based on physical phenomena; the evaluation of footwear uses practical aspects related to availability and the comfort of the shoes, while the perception of the foot's general health is based on the patients' self-assessment of the state of their feet. Each question allows several answers and these are placed on a Likert-type ordinal scale (words or phrases corresponding to a numeric scale). The descriptors for these scales vary for each domain and the person completing the questionnaire has to choose only one response, whichever is thought to be the most appropriate. The questionnaire does not provide a global score, but rather generates an index for each domain. In order to obtain these indices, the responses are analyzed by a computer program (The FHSQ, Version 1.03) which, after processing the data, gives a score ranging from 0 to 100 . A 0 score represents 
the worst state of health for the foot and 100 is the best possible condition. Furthermore, the software also provides graphical images of the outcomes.

Section 2 includes questions that reflect four general health-related domains: general health, physical activity, social capacity, and vigor. The domains and questions in this section are largely adapted from the Medical Outcomes Study 36-Item Short-Form Health Survey, ${ }^{38}$ which has been validated for use in the Australian population..$^{39}$

Section 3 collects socioeconomic status, comorbidity, service utilization and satisfaction information and their medical record. This study was conducted according to the Strengthening the Reporting of Observational Studies in Epidemiology guidelines (STROBE). ${ }^{40}$

\section{ETHICAL CONSIDERATIONS}

This research was approved by the Research Ethics Committee at the University of A Coruña (Spain). All participants gave informed written consent before being included, and the ethical standards in human experimentation contained in the WMA Declaration of Helsinki, the Council of Europe Convention on $\mathrm{Hu}-$ man Rights and Biomedicine, the UNESCO Universal Declaration on the Human Genome and Human Rights and those of the relevant national bodies and institutions were observed at all times.

\section{STATISTICAL ANALYSIS}

Statistical analyses were performed using IBM SPSS Statistics 19.0, Chicago, IL, USA for Windows. Qualitative variables are shown as absolute values and percentages, whilst the quantitative variables described are the mean, median, standard deviation (SD) and maximum and minimum values.

The Kolmogorov-Smirnov test was used to test the normality of the data and were considered normally distributed if $p>0.05$. The results of these tests indicated that the data were normally distributed and that parametric statistical tests were most appropriate. Independent Student t tests were performed to determine whether there were statistically significant differences in all variables between the two groups.

The Foot Health Status Questionnaire Version 1.03 was used to obtain quality of life scores related to foot health. In all of the analyses, $\mathrm{P}<0.01$ (with a 99\% confidence interval) was considered statistically significant. Data analysis was conducted with SPSS software, version 19.0 (SPSS Science, Chicago, Illinois).

\section{RESULTS}

\section{Sample characteristics}

A total of 120 women completed all stages of the research process. The mean age was $41.94 \pm 13.91$ years (range 18 to 65 ) for total population and in table 5 the clinical and sociodemographic characteristics of the participants are showed informants. As can be seen, is relevant that most informants are overweight $\left(\mathrm{BMI}=25.45 \pm 4.51 \mathrm{~kg} / \mathrm{m}^{2}\right)$. No statistically significant differences were found between the two groups for participant age, height, weight and BMI $(\mathrm{P}>0.01)$. The results for the variables measured are shown in Table 1.

In what regards the comparison of the scores obtained with the FHSQ, results appear on Table 2.

TABLE 1 - SOCIO-DEMOGRAPHIC AND CLINICAL CHARACTERISTICS OF THE SAMPLE POPULATION

\begin{tabular}{l|l|l|l|l}
\hline & $\begin{array}{l}\text { Total Group } \\
\text { Mean } \pm \text { SD } \\
\text { Range N=120 }\end{array}$ & $\begin{array}{l}\text { Heel height shoes Mean } \\
\pm \text { SD } \\
\text { Range N=60 }\end{array}$ & $\begin{array}{l}\text { No Heel height shoes } \\
\text { Mean } \pm \text { SD } \\
\text { Range N=60 }\end{array}$ & P Value \\
\hline Age, years & $\begin{array}{l}41.94 \pm 13.91 \\
(18-65)\end{array}$ & $\begin{array}{l}41.25 \pm 11.99 \\
(18-63)\end{array}$ & $\begin{array}{l}42.63 \pm 15.66 \\
(20-65)\end{array}$ & 0.588 \\
\hline Weight $(\mathrm{kg})$ & $\begin{array}{l}67.27 \pm 12.67 \\
(45-110)\end{array}$ & $\begin{array}{l}66.05 \pm 12.65 \\
(45-110)\end{array}$ & $\begin{array}{l}68.49 \pm 12.67 \\
(48-110)\end{array}$ & 0.294 \\
\hline Height $(\mathrm{cm})$ & $162.49 \pm 6.45$ & $\begin{array}{l}163.38 \pm 6.225 \\
(150-176)\end{array}$ & $\begin{array}{l}161.60 \pm 6.61 \\
(150-174)\end{array}$ & 0.130 \\
\hline BMI $(\mathrm{kg} / \mathrm{m} 2)$ & $(150-176)$ & $24.71 \pm 4.52$ & $26.18 \pm 4.42$ \\
$(19.16-42.97)$ & 0.074 \\
\hline
\end{tabular}

Abbreviations: BMI, body mass index; SD, standard deviation. In all the analyses, $P<.01$ (with a $99 \%$ confidence interval) was considered statistically significant. P-values are from Independent student t-test. 
These scores were lower for the group of women that use HHS, both in the first section of the questionnaire, which assesses the informants' quality of life related specifically to foot health, and in the second section, which assesses the informants' health in general related informants without HHS, with normalized reference values,

The differences between the two groups were statistically significant $(\mathrm{p}<0.05)$ for those dimensions in the questionnaire which assessed foot pain and general foot health.

\section{DISCUSSION}

The purpose of this study was to describe and compare the scores obtained with regard to foot health and health in general in a sample of women that use HHS as opposed to a sample of women without HHS with normalized reference values.

Women people are the predominate wearers of HHS, and the gender that have the highest rate of lower limb health problems, painful and disabling conditions. ${ }^{41,42}$ Although none has focused on the relationships HHS and quality of life related to foot health.

The study outlined in this protocol is, therefore, novel in that it targets a HHS used by those females that spent the same amount of time walking at the day, including after-work and weekend. In our study, participants with HHS present lower scores in quali- ty of life related to health in general on all the dimensions related to foot health specifically: foot pain, foot function, footwear and general foot health and in general on all the dimensions related to general health, physical activity, social capacity and vigor than women without HHS with normalized reference values. Our results are in line with a systematic review of Barnish et al indicating that HHS and musculoskeletal injuries has been strongly associated with poor foot health. ${ }^{43}$

However, our findings need to be interpreted in the context of several methodological limitations that should be acknowledged. First this research excluded people who required custom shoes or custom inserts. Second, our footwear assessment tool was limited to one key feature: HHS and no other characteristics of shoe toe-box shape. Third, a larger and more diverse (individuals from various countries) sample size would be beneficial to improve the strength of the study. Fourth, expanding data collection to other countries may help to identify if there is a culture where this association does not exist and identify the mechanisms involved.

This highlights the need for further research on the presence and severity of HHS and how it influences on the foot in order to improve women's health, quality of life and autonomy. The longitudinal cohort studies may be useful to study the shoes heel effect along the time.

TABLE 2 - FHSQ MEAN SCORES FOR THE CASE AND CONTROL GROUPS.

\begin{tabular}{|c|c|c|c|c|}
\hline & $\begin{array}{c}\text { Total Group Mean (SD) } \\
\text { Range } N=120\end{array}$ & $\begin{array}{l}\text { Heel height shoes Mean (SD) } \\
\text { Range } N=60\end{array}$ & $\begin{array}{c}\text { No Heel height shoes } \\
\text { Mean (SD) } \\
\text { Range } \mathrm{N}=60\end{array}$ & P Value \\
\hline Foot Pain & $\begin{array}{l}71.93 \pm 21.39 \\
(0-100)\end{array}$ & $\begin{array}{l}65.86 \pm 22.76 \\
(0-100)\end{array}$ & $\begin{array}{l}78.00 \pm 18.17 \\
(19-100)\end{array}$ & 0.001 \\
\hline Foot Function & $\begin{array}{l}76.56 \pm 27.98 \\
(0-100)\end{array}$ & $\begin{array}{l}66.46 \pm 32.19 \\
(0-100)\end{array}$ & $\begin{array}{l}86.67 \pm 18.32 \\
(0-100)\end{array}$ & 0.001 \\
\hline Footwear & $\begin{array}{l}51.46 \pm 31.33 \\
(0-100)\end{array}$ & $\begin{array}{l}45.42 \pm 31.12 \\
(0-100)\end{array}$ & $\begin{array}{l}57.50 \pm 30.63 \\
(0-100)\end{array}$ & 0.034 \\
\hline General Foot Health & $\begin{array}{l}56.50 \pm 30.21 \\
(0-100)\end{array}$ & $\begin{array}{l}48.37 \pm 28.67 \\
(0-100)\end{array}$ & $\begin{array}{l}64.63 \pm 29.74 \\
(0-100)\end{array}$ & 0.002 \\
\hline Social Capacity & $\begin{array}{l}72.81 \pm 33.39 \\
(0-100)\end{array}$ & $\begin{array}{l}58.96 \pm 37.82 \\
(0-100)\end{array}$ & $\begin{array}{l}86.67 \pm 20.69 \\
(0-100)\end{array}$ & 0.001 \\
\hline Vigor & $\begin{array}{l}61.09 \pm 26.38 \\
(0-100)\end{array}$ & $\begin{array}{l}51.87 \pm 25.01 \\
(0-100)\end{array}$ & $\begin{array}{l}70.31 \pm 24.61 \\
(13-100)\end{array}$ & 0.001 \\
\hline
\end{tabular}

Abbreviations: FHSQ = Foot Health Status Questionnaire Survey;. SD, standard deviation. In all the analyses, $\mathrm{P}<.01$ (with a 99\% confidence interval) was considered statistically significant. P-values are from Independent student t-test 


\section{CONCLUSION}

This study provides evidence that women who wear HHS have a negative impact on the quality of life regarding foot health. These findings suggest that advising women to minimize their use of HHS may have long-term benefits on general health, and this could be investigated in future studies.

\section{Declaration of Funding and Role of Funding} None.

\section{Conflict of Interest}

The authors did not receive any financial assistance and they do not have any personal relationships with any other people or organizations that could inappropriately influence (bias) their work.

\section{Author contributions}

All authors: concept, design, analysis, interpretation of data, drafting of manuscript or revising it critically for important intellectual content.

\section{RESUMO}

Muitas mulheres usaram sapatos de salto alto (SSA) em algum momento de suas vidas e muitas usam diariamente, com maior prevalência entre 39\% e 78\%, observadas em contextos institucionais e clínicos. O objetivo deste estudo foi descrever e comparar os escores obtidos em relação à saúde dos pés e à saúde em geral em uma amostra de mulheres que utilizam SSA em oposição a uma amostra de mulheres sem SSA com valores de referência normalizados. Uma amostra de 120 participantes com idade média de $41,94 \pm 13,912$ chegou a um centro de saúde onde os dados autorrelatados foram registrados, os informantes com e sem SSA foram determinados e os escores obtidos foram comparados no Foot Health Status Questionnaire (FHSQ). Esse documento tem 13 questões que avaliam quatro domínios de saúde dos pés, nomeadamente dor, função, saúde geral e calçado. As mulheres do grupo SSA apresentaram pior qualidade de vida relacionada à saúde em geral e à saúde dos pés, especificamente. As diferenças entre os dois grupos foram avaliadas por meio de um teste $\mathbf{t}$ para amostras independentes, mostrando significância estatística $(P<0,01)$. As mulheres com SSA apresentam um impacto negativo na qualidade de vida relacionada à saúde dos pés.

PALAVRAS-ChaVE: Deformidades do pé. Doenças do pé. Qualidade de vida. Sapatos.

\section{REFERENCES}

1. Frey C, Thompson F, Smith J, Sanders M, Horstman H. American Orthopaedic Foot and Ankle Society women's shoe survey. Foot Ankle. 1993;14(2):78-81.

2. Yoon $M, A n D H$, Yoo WG, Kwon $Y R$. Differences in activities of the lower extremity muscles with and without heel contact during stair ascent by young women wearing high-heeled shoes. J Orthop Sci. 2009;14(4):418-22

3. American Podiatric Medical Association (APMA). High heel survey; 2003 [cited 2017 Jun 7] Available from: http://www.apma.org/s_apma/doc.asp?CID=1233\&DID=17112.2003/.

4. The Ogilvy Group. British women's daily battle with high heels; 2007. [cited 2017 Jun 7] Available from: http://www.feetforlife.org/cgibin/item. cgi? $i d=1850 \& d=$ pnd \& $h=0 \& f=0 \&$ dateforma $-t=\% 250 \% 20 \% 25 B \% 20 \% 25 Y$.

5. Craik J. Fashion: the key concepts. Oxford: Berg; 2009.

6. Linder M. Smart women, stupid shoes, and cynical employers: the unlawfulness and adverse health consequences of sexually discriminatory workplace footwear requirements for female employees. J Corp Law. 1997;22(2):295-329.

7. Srivastava A, Mishra A, Tewari RP. Electromyography analysis of high heel walking. Int J Electron Comm Tech. 2012;3(1):166-9.

8. Schaefer S, Lindenberger U. Thinking while walking: experienced highheel walkers flexibly adjust their gait. Front Psychol. 2013;4:316.

9. Small L. Killer heels: the art of the high-heeled shoe. Munich: Prestel; 2014.
10. Guéguen N. High heels increase women's attractiveness. Arch Sex Behav. 2015;44(8):2227-35

11. Morris PH, White J, Morrison ER, Fisher K. High heels as supernormal stimuli: how wearing high heels affects judgements of female attractiveness. Evol Hum Behav. 2013; 34(3):176-81.

12. Goud A, Khurana B, Chiodo C, Weissman BN. Women's musculoskeletal foot conditions exacerbated by shoe wear: an imaging perspective. Am J Orthop (Belle Mead NJ). 2011;40(4):183-91.

13. Foster $A$, Blanchette MG, Chou YC, Powers CM. The influence of heel height on frontal plane ankle biomechanics: implications for lateral ankle sprains. Foot Ankle Int. 2012;33(1):64-9.

14. Iqbal R, De A, Mishra W, Maulik S, Chandra AM. Study on lumbar kinematics and the risk of low back disorder in female university students by using shoes of different heel heights. Work. 2012;41(Suppl. 1):2521-6.

15. Luximon $Y$, Cong $Y$, Luximon $A$, Zhang $M$. Effects of heel base size, walking speed, and slope angle on center of pressure trajectory and plantar pressure when wearing high-heeled shoes. Hum Mov Sci. 2015; $41: 307-19$

16. Frey C, Coughlin MJ. Women's shoe wear: an orthopaedist's advice. J Womens Health. 1999;8(1):45-9.

17. Kerrigan DC, Johansson JL, Bryant MG, Boxer JA, Della Croce U, Riley PO. Moderate-heeled shoes and knee joint torques relevant to the development and progression of knee osteoarthritis. Arch Phys Med Rehabil. 2005;86(5):871-5. 
18. Chien HL, Lu TW, Liu MW. Control of the motion of the body's center of mass in relation to the center of pressure during high-heeled gait. Gait Posture. 2013;38(3):391-6.

19. Blanchette MG, Brault JR, Powers CM. The influence of heel height on utilized coefficient of friction during walking. Gait Posture. 2011;34(1):10710

20. Tedeschi Filho W, Dezzotti NR, Joviliano EE, Moriya T, Piccinato CE. Influence of high-heeled shoes on venous function in young women. J Vasc Surg. 2012;56(4):1039-44.

21. Dunn JE, Link CL, Felson DT, Crincoli MG, Keysor JJ, McKinlay JB. Prevalence of foot and ankle conditions in a multiethnic community sample of older adults. Am J Epidemiol. 2004;159(5):491-8.

22. Dawson J, Thorogood M, Marks SA, Juszczak E, Dodd C, Lavis G, et al. The prevalence of foot problems in older women: a cause for concern. J Public Health Med. 2002;24(2):77-84.

23. Coughlin MJ, Thompson FM. The high price of high-fashion footwear. Instr Course Lect. 1995;44:371-7.

24. Frey C, Thompson F, Smith J. Update on women's footwear. Foot Ankle Int. 1995;16(6):328-31.

25. Palomo-López P, Becerro-de-Bengoa-Vallejo R, Losa-lglesias ME, Rodríguez-Sanz D, Calvo-Lobo C, López-López D. Impact of hallux valgus related of quality of life in women. Int Wound ). 2017;14(5):782-5.

26. López-López D, Rodríguez-Vila I, Losa-Iglesias ME, Rodríguez-Sanz D Calvo-Lobo C, Romero-Morales C, et al. Impact of the quality of life related to foot health in a sample of pregnant women: a case control study. Medicine (Baltimore). 2017;96(12):e6433.

27. López López D, Rivas López M, Bouza Prego ML, María Mónaco L, Losa Iglesias ME, Saleta Canosa JL, et al. Quality of life impact related to foot health in a sample of sea workers. J Tissue Viability. 2015;24(4):146-52.

28. Irving DB, Cook JL, Young MA, Menz HB. Impact of chronic plantar heel pain on health-related quality of life. J Am Podiatr Med Assoc. 2008;98(4):283-9.

29. Cuesta-Vargas A, Bennett P, Jimenez-Cebrian AM, Labajos-Manzanares MT. The psychometric properties of the Spanish version of the Foot Health Status Questionnaire. Qual Life Res. 2013;22(7):1739-43.
30. Garrow JS, Webster J. Quetelet's index (W/H2) as a measure of fatness. Int J Obes. 1985;9(2):147-53.

31. Choi H, Park H, Kim Y. Foot-ankle roll-over characteristics in different heel heights during walking. Conf Proc IEEE Eng Med Biol Soc. 2005;7:6882-4.

32. Cong Y, Cheung JT, Leung AK, Zhang M. Effect of heel height on inshoe localized triaxial stresses. J Biomech. 2011;44(12):2267-72.

33. Bennett PJ, Patterson C, Wearing S, Baglioni T. Development and validation of a questionnaire designed to measure foot-health status. J Am Podiatr Med Assoc. 1998;88(9):419-28.

34. Bennett PJ, Patterson C, Dunne MP. Health-related quality of life following podiatric surgery. I Am Podiatr Med Assoc. 2001;91(4):164-73.

35. Landor KB, Keenan AM. An evaluation of two foot-specific, health-related quality-of-life measuring instruments. Foot Ankle Int. 2002;23(6):538-46.

36. Ware JE Jr, Sherbourne CD. The MOS 36-item short-form health survey (SF-36). I. Conceptual framework and item selection. Med Care. 1992;30(6):473-83.

37. Bennet PJ, Patterson C. The Foot Health Status Questionnaire (FHSQ): a new instrument for measuring outcomes of footcare. Aust J Podiatr Med. 1998;32(1):87.

38. Ware JE JR. SF-36 Health survey: manual and interpretation guide. Boston: Health Institute, New England Medical Centre; 1993.

39. McCallum J. The SF-36 in an Australian sample: validating a new, generic health status measure. Aust J Public Health. 1995;19(2):160-6.

40. White RG, Hakim AJ, Salganik MI, Spiller MW, Johnston LG, Kerr L, et al. Strengthening the reporting of observational studies in epidemiology for respondent-driven sampling studies: "STROBE-RDS" statement. J Clin Epidemiol. 2015;68(12):1463-71.

41. Yung-Hui L, Wei-Hsien $H$. Effects of shoe inserts and heel height on foot pressure, impact force, and perceived comfort during walking. Appl Ergon. 2005;36(3):355-62.

42. Cowley EE, Chevalier TL, Chockalingam N. The effect of heel height on gait and posture: a review of the literature. J Am Podiatr Med Assoc. 2009;99(6):512-8.

43. Barnish MS, Barnish J. High-heeled shoes and musculoskeletal injuries: a narrative systematic review. BMJ Open. 2016;6(1):e010053. 